\title{
Friction characteristics between metal tool and wood impregnated with phenol formaldehyde (PF) resin during exposure to high pressure
}

\author{
Masako Seki $^{1} \cdot$ Soichi Tanaka $^{2} \cdot$ Tsunehisa Miki $^{1} \cdot$ Ichinori Shigematsu $^{1} \cdot$ \\ Kozo Kanayama ${ }^{2}$
}

Received: 26 August 2015/Accepted: 2 March 2016/Published online: 24 March 2016

(C) The Japan Wood Research Society 2016

\begin{abstract}
Friction between metal tools and wood under high pressure $(\geq 1 \mathrm{MPa})$ necessarily arises during wood deformation processes and is thus an important factor to be taken into account when wood is processed. We focus on the friction characteristics between a metal tool and wood impregnated with phenol formaldehyde (PF) resin, which is widely used to improve the dimensional stability of wood products. To clarify the effects of the metal tool surface temperature, the PF resin concentration of impregnated solution and the lubricants under exposure to high pressure on the friction characteristics, the friction coefficient $(\mu)$ was measured while the wood was compressed in the tangential direction at high pressure (6.7 MPa). The results of $\mu$ for higher PF resin concentration differed significantly with the temperature of the metal tool surface. When the impregnated specimens slide under softening temperature $\left(\leq 140{ }^{\circ} \mathrm{C}\right)$, the PF resin squeezing out from the specimen contributed to a decrease of $\mu$ because it acts as a lubricant. However, when the impregnated specimens were cured $\left(160{ }^{\circ} \mathrm{C}\right), \mu$ increased due to an increase of the sliding resistance on the contact surface. $\mu$ was decreased to 0.02 when using a release agent for commodity plastics as a lubricant.
\end{abstract}

Keywords Friction $\cdot$ High pressure $\cdot$ Phenol formaldehyde resin - Lubricant

Masako Seki

m-seki@aist.go.jp

1 Structural Materials Research Institute, National Institute of Advanced Industrial Science and Technology, Nagoya, Aichi 463-8560, Japan

2 Research Institute for Sustainable Humanosphere, Kyoto University Gokasho, Uji, Kyoto 611-0011, Japan

\section{Introduction}

Wood forming processes such as compression and bending of solid wood have been researched from various aspects [1]. In these processes, simple shape products can be obtained by wood cell deformation under high pressure ( $\geq 1 \mathrm{MPa}$ ). In addition to these conventional techniques, a new forming process of wood flow forming has been developed to enable the processing of solid wood into more complex forms within a shorter production time [2-4]. This new technique is caused not only by cell deformation, but also by mutual position changes between adjacent wood cells.

After these deformation processes, the deformed wood (products) must have their shape fixed. One effective method to overcome the dimensional instability of the products due to moisture is the impregnation of low molecular weight resins, such as phenol formaldehyde (PF) resin, into the wood prior to the forming process [3-5]. Low molecular weight PF resin can penetrate into the cell walls and softens them, so that PF resin-impregnated woods can be compressed under pressure of more than approximately $2 \mathrm{MPa}$ with heating [6]. After curing under pressure and heat, the impregnated $\mathrm{PF}$ resin is polymerized to form a rigid cross-linked network in the cell wall, which prevents recovery of the original shape and results in a compressed and densified form of wood. The PF resinimpregnated compressed wood, which is generically referred to as Compreg, has been used for applications such as furniture and flooring because of its high dimensional stability and mechanical properties [7].

When wood is subjected to deformation processes, relatively high pressures $(\geq 1 \mathrm{MPa})$ are generally applied. Under such conditions, the processed wood is exposed to high friction force that arises between the wood and the 
tools used, which can generate wear on the tools and can also have a large impact on the forming limits of the material.

The authors [8-10] have previously reported that the friction characteristics during exposure to relatively high pressure ( $\geq 1 \mathrm{MPa}$ ) are different form those during exposure to relatively low pressures $(\leq 0.1 \mathrm{MPa})$. Under low pressure, the interface contact characteristics have a large influence on the friction characteristics [11]. The friction characteristics under high pressure are not only affected by the interface contact characteristics, but also by the inner structure and mechanical properties of the wood, which vary depending on the pressure, moisture content, and anisotropy of the wood. However, we have not yet reported the friction characteristics of resin-impregnated wood.

Furthermore, the use of lubricants is necessary to achieve successful forming, especially for complex shaped products, although the effect on the friction characteristics during the forming process is still unclear.

The major objective of our study was to clarify the friction characteristics between metal tools and PF resinimpregnated wood during the forming process. The effects of the metal tool surface temperature, the PF resin concentration of impregnated aqueous solution, and lubricants under high pressure on the friction characteristics were investigated. The friction coefficient $(\mu)$ between metal tools and PF resin-impregnated wood specimens was measured during compression in the tangential direction at high pressure $(6.7 \mathrm{MPa})$, and the wood specimens and metal tools were then optically inspected to consider the factors that influence the friction characteristics.

\section{Materials and methods}

\section{Sample preparations}

Wood specimens with dimensions of $30 \mathrm{~mm}$ (L; longitudinal direction $) \times 30 \mathrm{~mm}(\mathrm{R}$; radial direction $) \times 5 \mathrm{~mm}(\mathrm{~T}$; tangential direction) were successively cut from a block of hinoki (Chamaecyparis obtusa). The friction surfaces of wood [30 mm (L) $\times 30 \mathrm{~mm}(\mathrm{R})]$ were finished using an electric planer (Ryobi, HL-6A). The density of a completely dried wood specimen was approximately $0.32 \mathrm{~g} / \mathrm{cm}^{3}$.

Wood specimens were leached in ethanol to remove natural extractives and then completely oven-dried at $105{ }^{\circ} \mathrm{C}$. Dried specimens were impregnated with PF resin having an average molecular weight of less than 500 (PX341, Aica Kogyo Company) conditioned into various concentrations (solid contents of PF resin were $0,5,10,20$, 30 , and $50 \%$ ) under reduced pressure (0.01 MPa) for $1 \mathrm{~h}$ and under pressure $(0.8 \mathrm{MPa})$ for $18 \mathrm{~h}$ at room temperature. Impregnated specimens were gently dried under room temperature conditions for $24 \mathrm{~h}$, air-dried at $35{ }^{\circ} \mathrm{C}$ for $120 \mathrm{~h}$, and then vacuum dried completely at $35^{\circ} \mathrm{C}$ for $48 \mathrm{~h}$ with phosphorus pentoxide $\left(\mathrm{P}_{2} \mathrm{O}_{5}\right)$. Weight per gain (WPG) and swelling in the $\mathrm{T}$ direction of five specimens due to the treatment were determined using the completely dried weight and dimensions before and after the treatment.

\section{Thermal analysis}

A small test piece $\left(1.5 \times 1.5 \times 1.5 \mathrm{~mm}^{3}\right)$ cut from the impregnated and dried wood specimen was subjected to dynamic mechanical analysis (DMA; SII NanoTechnology Inc., TMA SS6100). An oscillating compressive load of $200 \pm 100 \mathrm{mN}$ in the $\mathrm{T}$ direction was applied to the test specimen and dry nitrogen gas was purged during the measurement, while heating under one of the following two schedules. Firstly, to determine the thermal softening and hardening of wood specimens conditioned with various $\mathrm{PF}$ resin concentrations, the test specimen was heated from 60 to $180{ }^{\circ} \mathrm{C}$ under a constant heating rate of $5{ }^{\circ} \mathrm{C} / \mathrm{min}$. Secondly, to determine the relationship between the heating time and thermal hardening of $\mathrm{PF}$ resin-impregnated specimens using PF resin solution at a concentration of $30 \%$, the test specimen was rapidly heated from $60{ }^{\circ} \mathrm{C}$ to each temperature $\left(80,120,140\right.$, and $\left.160{ }^{\circ} \mathrm{C}\right)$ at a heating rate of approximately $20{ }^{\circ} \mathrm{C} / \mathrm{min}$ and kept constant at that temperature for $10 \mathrm{~min}$. These analyses were conducted three times.

\section{Measurement of friction coefficient}

The PF resin-impregnated and dried specimens were pasted to the upper and under surfaces of a free-cutting brass cube (35 mm) using a cyanoacrylate adhesive (the left hand side of Fig. 1). The specimens were rubbed against a metal tool (SKD11 alloy tool steel) and the friction surfaces of the tools $(50 \mathrm{~mm} \times 100 \mathrm{~mm})$ were finished by polishing. The surface roughness of the sliding direction was measured by the stylus method using a surface roughness tester (Mitutoyo, SJ-500) and surface parameters were calculated based on ISO 4287 [12]. The arithmetical mean deviation $R_{\mathrm{a}}$, was less than $0.05 \mu \mathrm{m}$ and the maximum height $R_{\mathrm{z}}$, was less than $0.69 \mu \mathrm{m}$.

Figure 1 (right hand side) shows the setup for measurement of the friction coefficient. The friction coefficients were measured using a dynamic biaxial testing system (Saginomiya, V-1815). The metal tools were fixed to the upper and lower pressure plates, and their surfaces were heated at four temperatures $(80,120,140$, and $\left.160{ }^{\circ} \mathrm{C}\right)$. The friction surfaces of the wood specimens $[30 \mathrm{~mm}(\mathrm{~L}) \times 30 \mathrm{~mm}(\mathrm{R})]$ at room temperature were placed in contact with the heated metal tools without contact of the brass cube with the stem. After $50 \mathrm{~s}$ of 
Fig. 1 Schematic illustration of the setup for friction coefficient ( $\mu$ ) measurements

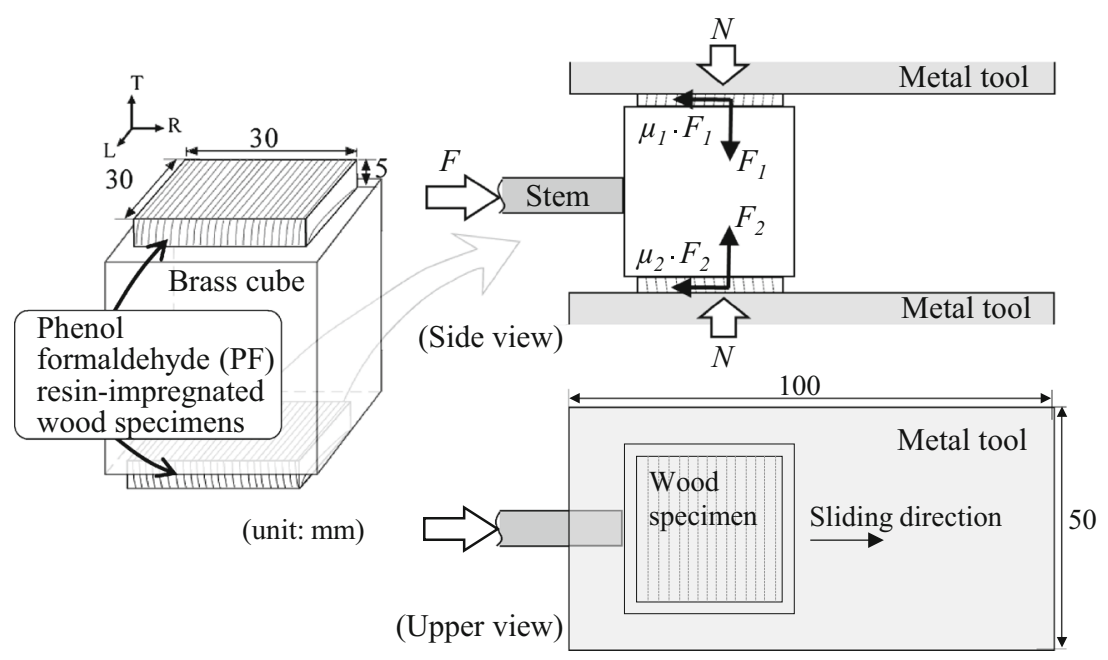

contact with the metal tools, the wood specimens were compressed perpendicular to the contact surfaces at pressing speeds of $10 \mathrm{kN} / \mathrm{min}$ up to $6 \mathrm{kN}$ (nominal load $N$; pressure applied to the nominal contact area $\left(30 \times 30 \mathrm{~mm}^{2}\right)$ at $\left.6.7 \mathrm{MPa}\right)$. After the $N$ was loaded to the specimens, $90 \mathrm{~s}$ after contact with the metal tools, a stem was moved at a constant speed $(30 \mathrm{~mm} / \mathrm{min})$ to slide the wood specimen in the $\mathrm{R}$ direction with a constant $N$ of $6 \mathrm{kN}$ while the force $F$, loaded to the stem was measured. Assuming that the force $\left(F_{1}\right)$ and friction coefficient $\left(\mu_{1}\right)$ on the upper contact surface were equal to those $\left(F_{2}\right.$ and $\left.\mu_{2}\right)$ on the lower contact surface, the friction coefficient $\mu$ was calculated using the following equation [8-10]:

$\mu=F / 2 F_{1}$.

The friction surfaces of the metal tools were cleaned with acetone prior to each measurement. In addition to the measurement with the cleaned tool surface, the metal tool surfaces were sprayed with lubricant (Pelicoat S, Chukyo Kasei Kogyo Co., Ltd.), a vegetable oil-based mold release agent for commodity plastics, and measurements were conducted with specimens impregnated with $30 \%$ PF resin that were moved on the metal tool surfaces heated at $140{ }^{\circ} \mathrm{C}$. To investigate the detailed friction characteristics, the sampling time was set as $10 \mathrm{~ms}$. The measurements were conducted twice to confirm the reproducibility of the friction coefficient for each measurement condition.

\section{Results and discussion}

\section{WPG and swelling}

Figure 2 shows the relation between the PF resin concentration and the average of WPG or swelling in the

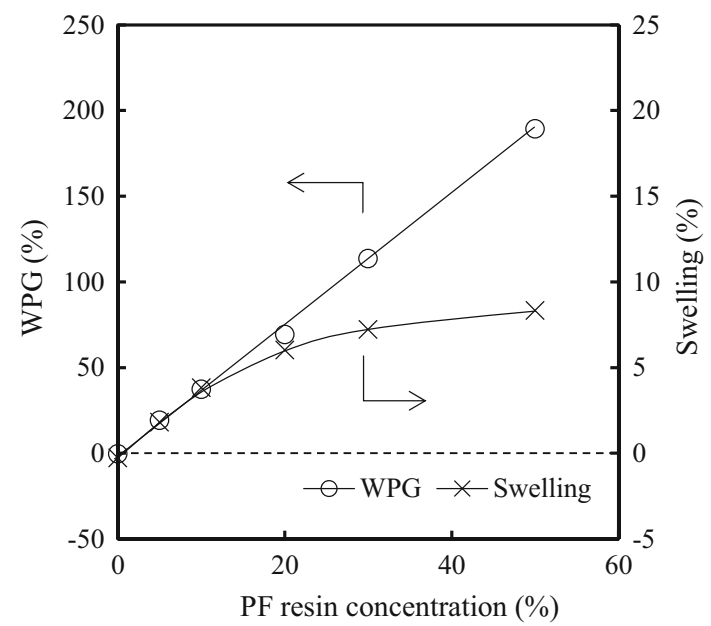

Fig. 2 Relation between the phenol formaldehyde (PF) resin concentration and weight per gain (WPG) or swelling in the tangential direction of the impregnated wood specimens

tangential direction of the impregnated wood specimens. The WPG increased linearly with the PF resin concentration. On the other hand, swelling increased rapidly with the increase in the $\mathrm{PF}$ resin concentration at lower $\mathrm{PF}$ resin concentrations and then only slightly increased at higher PF resin concentrations ( $\geq 20 \%)$. It is known that phenolic resin with average molecular weight of approximately 500 can penetrate into cell walls and then swells the woods [13, 14]. From these reports, the results in Fig. 2 suggest that the amount of PF resin in the cell walls increases with the PF resin concentration at lower concentration. In contrast, at higher PF resin concentrations, it is speculated that the amount of PF resin in the cell walls increases only slightly, whereas that in the cell lumens increases more significantly. 


\section{Thermal behavior of the wood specimens}

Figure 3 shows thermal analysis results with respect to the relative storage elastic modulus. The relative storage elastic modulus $\left(E^{\prime} / E^{\prime} 60{ }^{\circ} \mathrm{C}\right)$ was defined as the ratio of the storage elastic modulus measured at each temperatures to the storage elastic modulus measured at $60{ }^{\circ} \mathrm{C}$. The relative storage elastic modulus for the untreated sample showed no significant change during the measurement. Impregnation of PF resin into the wood specimens resulted in significant changes in the relative storage elastic moduli, whereby it decreased with elevating temperature from the beginning $\left(60{ }^{\circ} \mathrm{C}\right)$ to approximately $120^{\circ} \mathrm{C}$ and then increased from approximately $130{ }^{\circ} \mathrm{C}$. This result indicates that the PF resin-impregnated woods soften at temperatures lower than $120^{\circ} \mathrm{C}$ and harden by curing of the $\mathrm{PF}$ resin from approximately $130{ }^{\circ} \mathrm{C}$. These changes became more significant with an increase in the WPG of the PF resin-impregnated specimens.

In general, in the wood forming processes, tools used are heated before or after hardening of the wood materials. Therefore, considering the results in Fig. 3, metal tools were heated in the temperature range before and after hardening of the PF resin-impregnated specimens $(80,120$, 140 , and $160{ }^{\circ} \mathrm{C}$ ) for $\mu$ measurements.

Figure 4 shows the relationship between the normalized storage elastic modulus of the PF resin-impregnated specimens and retention time under each constant temperature. The relative storage elastic modulus showed no significant change at $80{ }^{\circ} \mathrm{C}$ for $10 \mathrm{~min}$, a slight increase with the heating time at $120{ }^{\circ} \mathrm{C}$, a gradual increase soon after the measurement start and almost reaching equilibrium after $4 \mathrm{~min}$ at $140{ }^{\circ} \mathrm{C}$, and a higher value at $160{ }^{\circ} \mathrm{C}$ from the beginning and a rapid increase to reach a maximum value

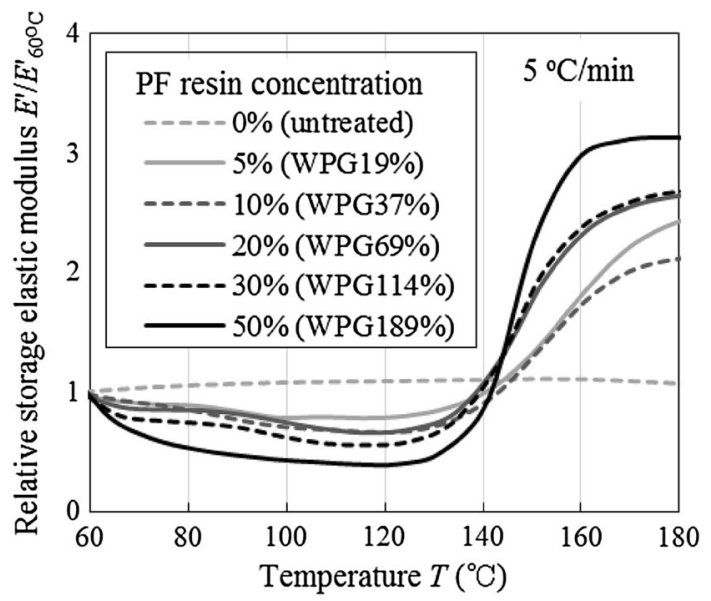

Fig. 3 Relationship between temperature and normalized storage elastic modulus of the wood specimens conditioned with various phenol formaldehyde $(\mathrm{PF})$ resin concentrations

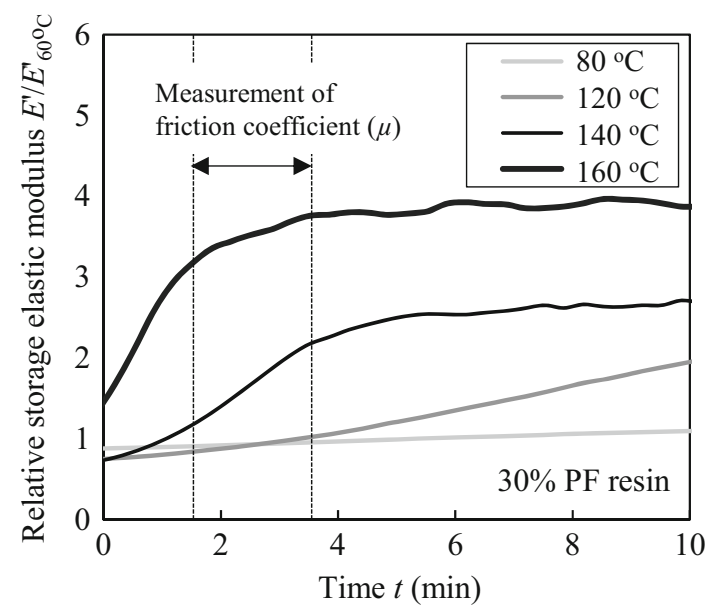

Fig. 4 Relationship between the retention time at each constant temperature and the relative (normalized) storage elastic modulus for phenol formaldehyde (PF) resin-impregnated wood specimens

after $2 \mathrm{~min}$. These results indicate that curing of the PF resin-impregnated specimen proceeds with time at temperatures of $120{ }^{\circ} \mathrm{C}$ or higher. Measurements of $\mu$ were started after $1.5 \mathrm{~min}$ and finished at $3.5 \mathrm{~min}$, during which the degree of curing in the $\mathrm{PF}$ resin-impregnated specimens changes with time, especially at $140{ }^{\circ} \mathrm{C}$.

\section{Effect of PF resin concentration and temperature on the friction characteristics}

Figure 5 shows the relationship between the stem displacement $D$, and $\mu$ (upper panels) and nominal compressive strain $\varepsilon$ (lower panels) for each PF resin concentration and temperature. With $D=0$ serving as the starting point of the load applied to the stem by the static friction between wood specimens and metal tools. The results indicate similar behavior of $\mu$ for PF resin concentrations of 0 and $5 \%$ (upper panels in Fig. 5). At both concentrations, $\mu$ increased with the $D$ at 80 and $160{ }^{\circ} \mathrm{C}$, and kept relatively constant value (in some cases vibration is generated by stick-slip) at 120 and $140{ }^{\circ} \mathrm{C}$. On the other hand, the behavior of $\mu$ for a PF resin concentration of $30 \%$ was totally different to that for PF resin concentrations of 0 and $5 \%$, and it differed significantly depending on the temperature. $\mu$ decreased with an increase in the $D$ when the specimen was sliding on $80{ }^{\circ} \mathrm{C}$ metal tool surface, at which the specimens start to soften. At $120^{\circ} \mathrm{C}$, where the specimen softens, $\mu$ oscillated due to stick-slip. $\mu$ increased with the $D$ at $140{ }^{\circ} \mathrm{C}$, where the specimens start to harden, and $\mu$ became significantly varied during the measurement at $160{ }^{\circ} \mathrm{C}$ at which the specimens hardened. The specimens stuck during the measurement at $140{ }^{\circ} \mathrm{C}$ and from the start at $160{ }^{\circ} \mathrm{C}$ [triangle $(\nabla)$ in Fig. 5]. The value of $\mu$ for a $\mathrm{PF}$ resin concentration of $30 \%$ was lower than that for 0 and $5 \%$ at all temperatures. 

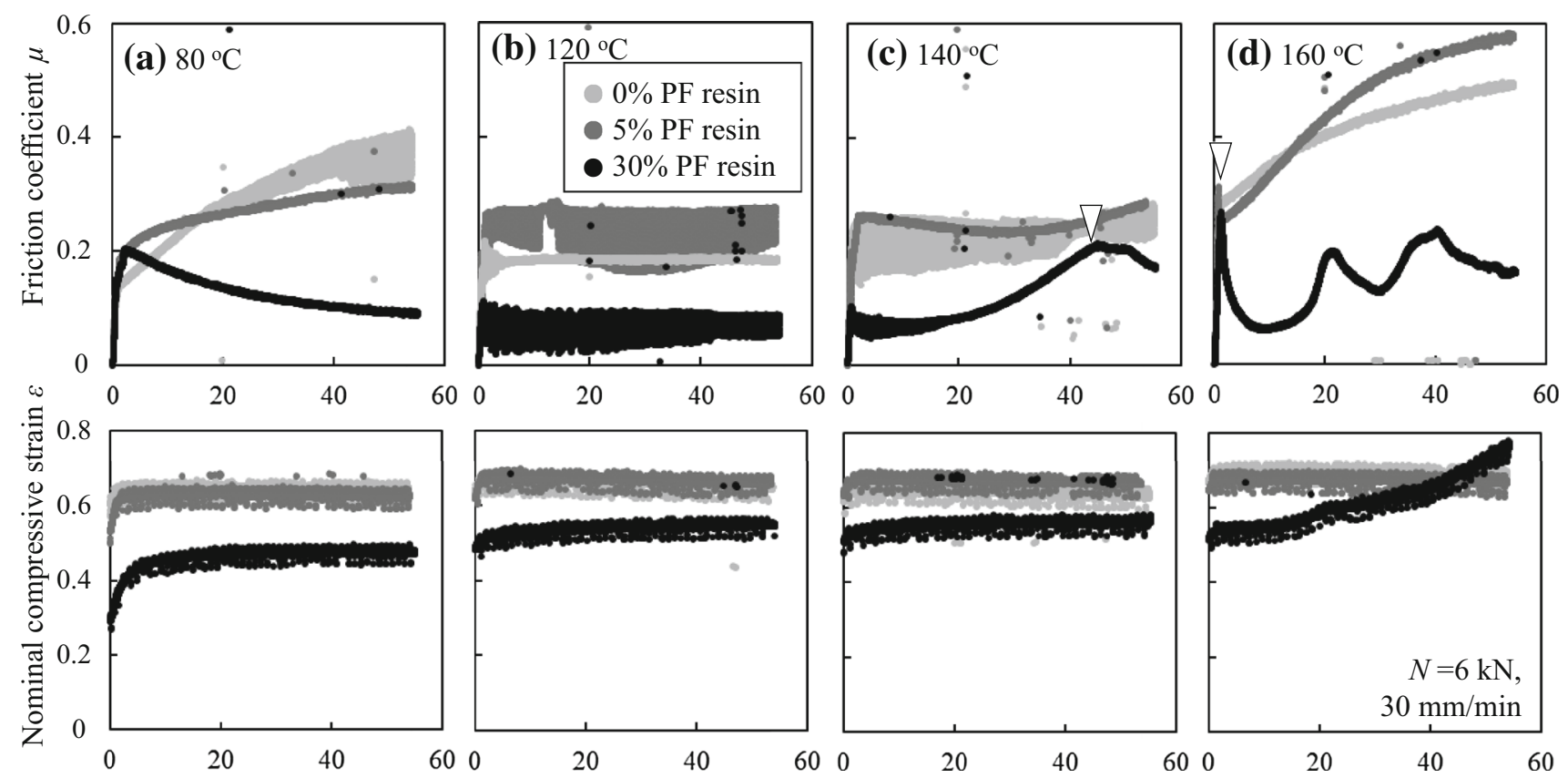

Fig. 5 Relationship between the stem displacement $(D)$, and friction coefficient ( $\mu$, upper graphs) and nominal compressive strain $(\varepsilon$, lower graphs) for each phenol formaldehyde (PF) resin concentration

To estimate the deformation of wood specimens during measurement, the nominal compressive strain $(\varepsilon)$ was calculated from the magnitude of movement between the upper and lower compression plates of the testing device. The value of $\varepsilon$ for PF resin concentrations of $30 \%$ was lower than 0 and $5 \%$ in the range from 80 to $140{ }^{\circ} \mathrm{C}$ (Fig. 5a-c). Most of the PF resin in the $5 \%$ PF resinimpregnated specimens was present in the cell walls, while that in the $30 \% \mathrm{PF}$ resin-impregnated specimens was present not only in the cell walls but also in the cell lumens (Fig. 2). Therefore, it seems that the 0 and $5 \%$ PF resinimpregnated specimens slide with their cell walls buckled and densified, whereas the $30 \% \mathrm{PF}$ resin-impregnated specimens could not be completely compressed because the cell lumens are filled with PF resin. The increase in $\varepsilon$ during the measurement at $160{ }^{\circ} \mathrm{C}$ (Fig. 5d) was not attributed to compression of the specimens but to the sticking of the specimens to the metal tool surface (as shown in Fig. 6).

Figure 7 shows the appearance of the wood specimens after the $\mu$ measurements. The untreated specimens (PF resin concentration of $0 \%$ ) showed no significant change at all temperatures examined. In contrast, the appearance of 5 and $30 \% \mathrm{PF}$ resin-impregnated specimens showed cured surfaces at 140 and $160{ }^{\circ} \mathrm{C}$ ( $\triangle$ in Fig. 7). The surfaces of the $30 \% \mathrm{PF}$ resin-impregnated specimens were damaged at 140 and $160{ }^{\circ} \mathrm{C}$, which indicate the sticking of the specimens during the measurement. The dotted circles in and temperature. Triangles show the starting point of the sticking friction of $30 \% \mathrm{PF}$ resin

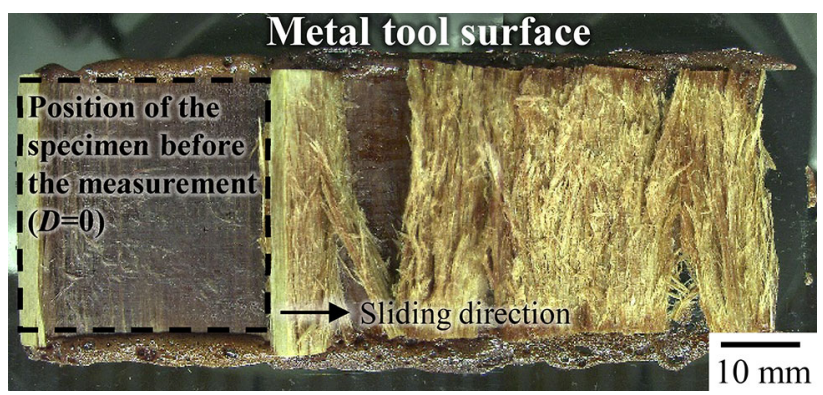

Fig. 6 Optical photograph of the $30 \%$ phenol formaldehyde (PF) resin-impregnated wood specimen stuck onto the metal tool surface after the $\mu$ measurement at $160{ }^{\circ} \mathrm{C}$

Fig. 7 indicate the seeping of PF resin from the end grains of the specimens.

Figure 6 shows an optical photograph of the $30 \% \mathrm{PF}$ resin-impregnated wood specimen stuck onto the metal tool surface after the $\mu$ measurement at $160{ }^{\circ} \mathrm{C}$. The result indicates that when the specimen was moved by stem, shearing fracture was generated inside the specimen where it was not yet hardened, because the resistance on the contact surface was sufficiently large to prevent slip between the metal tool and the wood specimen at $160{ }^{\circ} \mathrm{C}$, at which temperature the specimen was cured. It is known that shearing stress at an interface cannot exceed shearing strength of a material [15]. When the shearing stress at the interface becomes equal to the shearing strength of the 
Fig. 7 Appearance of the wood specimens after friction coefficient $(\mu)$ measurements. The triangles indicate those specimens with cured surfaces. Dotted circles indicate end grains of the specimens where phenol formaldehyde $(\mathrm{PF})$ resin is seeping onto the specimen surface
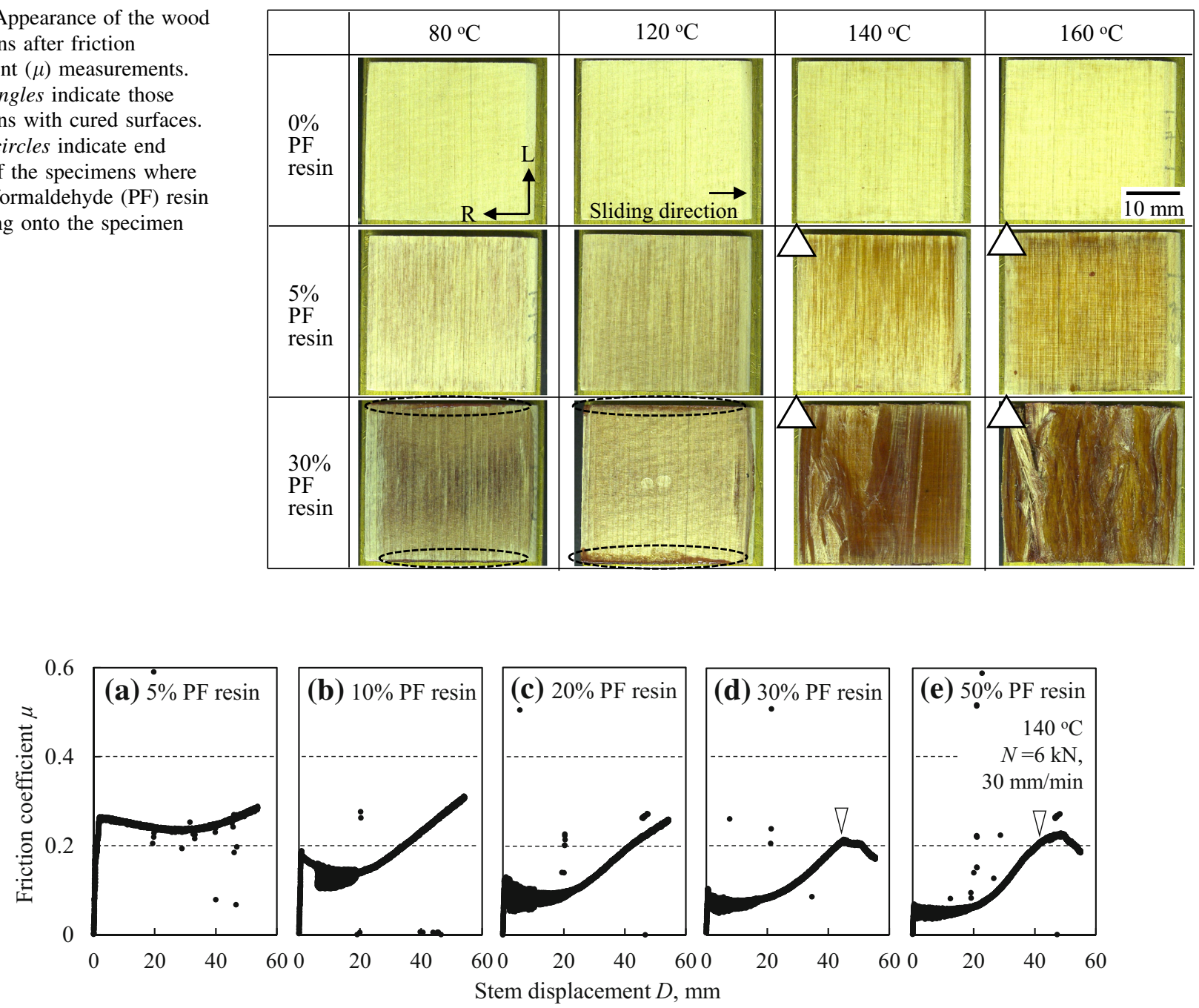

Fig. 8 Relationship between the stem displacement $(D)$ and friction coefficient $(\mu)$ for each phenol formaldehyde (PF) resin concentration at $140{ }^{\circ} \mathrm{C}$. Triangles indicate the starting point of the sticking friction

material, the slippage at the interface is stopped and shearing fracture is generated inside the material (sticking friction). In this case of sticking friction, the friction force is due not to shearing at the interface, but to shearing fracture [16]. It seems that the variation of $\mu$ at $160{ }^{\circ} \mathrm{C}$ for $30 \% \mathrm{PF}$ resin (Fig. 5) is attributed to repeated shearing fracture of the specimens and rubbing on the fractured surfaces.

The results of Figs. 4 and 5 indicate that the specimen for the $30 \% \mathrm{PF}$ resin-impregnated specimen at $160{ }^{\circ} \mathrm{C}$, of which the relative storage elastic modulus was high before the $\mu$ measurement [the retention time $(t)$ was up to $1.5 \mathrm{~min}$ in Fig. 5], was stuck from the start of the $\mu$ measurement (Fig. 4). In addition, the value of $\mu$ at $140{ }^{\circ} \mathrm{C}$, at which the relative storage elastic modulus of the specimens increased slightly before the measurement and gradually increased during the measurement $(t=1.5-3.5 \mathrm{~min}$ in Fig. 4), indicated a significant increase with the increase in $D$ until it was finally stuck. From these results, it is considered that curing in the PF resin-impregnated specimens near the contact surface increases the sliding resistance on the contact surface and generates sticking friction.

It has been previously reported that $\mu$ of water-swollen wood is lower than that of dry wood because the free water acts as a lubricant $[10,17]$. Therefore, the lower $\mu$ (lower than approximately 0.1 ) observed for the $30 \% \mathrm{PF}$ resinimpregnated specimens at 80,120 , and $140{ }^{\circ} \mathrm{C}$ in Fig. 5 seem to be caused by lubrication due to the seeping of PF resin from the specimens (as shown by the dotted circles in Fig. 7).

Figure 8 shows the relationship between the $D$ and $\mu$ for each $\mathrm{PF}$ resin concentration at $140{ }^{\circ} \mathrm{C}$. The higher PF resin concentrations resulted in lower $\mu$ at the beginning of the measurement $(D=0-20 \mathrm{~mm})$. From $D=20 \mathrm{~mm}, \mu$ increased with $D$ for all PF resin concentrations. 
For the beginning of the measurement, at which point the impregnated specimens are not sufficiently hardened ( $t=1.5-2.2 \mathrm{~min}$ of $140{ }^{\circ} \mathrm{C}$ in Fig. 4 ), it is considered that lubrication by $\mathrm{PF}$ resin seepage has a large effect on $\mu$. Figure 9 shows optical micrographs of the metal tool surfaces before and after the $\mu$ measurement at $140{ }^{\circ} \mathrm{C}$ for 0 , 30 and $50 \%$ PF resin-impregnated specimens at each $D$. Large amount of adherents were seen after the measurement (b)-(e) for 30 and $50 \%$ PF resin specimens, compared to the metal tool surfaces for $0 \% \mathrm{PF}$ resin specimen. At the beginning and middle of the measurement ( $D=0-35 \mathrm{~mm}$, Fig. 9b-d), gel-like adherents $(\triangle)$, which seem to be PF resin seeped through the specimen surface, were observed. The amount of adhered PF resin was larger in the $50 \% \mathrm{PF}$ resin specimen than in the $30 \% \mathrm{PF}$ resin specimen. This suggests that the $50 \%$ PF resin-impregnated specimen has a larger amount of PF resin that acts as a lubricant than the $30 \% \mathrm{PF}$ resin-impregnated specimen (Fig. 2), which results in a lower $\mu$ for the $50 \%$ PF resinimpregnated specimen due to the higher lubricating effect of PF resin when it is not cured. When $D$ was $35 \mathrm{~mm}$ (Fig. 9d), the amount of PF resin adherents decreased, and solid adherents $(\boldsymbol{\Delta})$ were observed when $D$ was $40 \mathrm{~mm}$ (Fig. 9e). Thus, the decrease in gel-like PF resin which acts as a lubricant resulted in an increase of $\mu$ during the measurement ( $D \geq 20 \mathrm{~mm}$ in Fig. 8).

\section{Relationship between PF resin concentration and stick-slip characteristics}

Figure 10 shows an enlargement of Fig. 8 for $D=12-13 \mathrm{~mm}$. The results indicated stick-slip, which is a phenomenon that involves repetition of the static and sliding states of a specimen [16], for all specimens except the $5 \% \mathrm{PF}$ resin specimen. The amplitude and cycle of the stick-slip behavior decreased with an increase in the PF resin concentration. The maximum value of $\mu$ during stick-slip which indicates the static friction coefficient [16] also decreased with an increase in the PF resin concentration. It is speculated that smaller static friction coefficient at higher $\mathrm{PF}$ resin concentration result from the higher lubricating effect of PF resin seepage through the specimen surface.

\section{Effect of lubricant on the friction characteristics}

Figure 11 shows relationship between $D$ and $\mu$ for $30 \%$ $\mathrm{PF}$ resin-impregnated specimen at $140{ }^{\circ} \mathrm{C}$ when the metal tool surfaces were sprayed with a lubricant. The value of $\mu$ was approximately 0.02 , which was significantly smaller compared with that for no lubricant (Fig. 8d), and there was no significant change during the measurement. It seems that the lubricant sprayed on the metal mold intervened at the interface between the metal tool and wood specimen during the measurement, and thus produced a significantly higher lubricating effect. Figure 12 shows the appearance of the $30 \%$ PF resin-impregnated specimen after the $\mu$ measurement with a lubricant at $140{ }^{\circ} \mathrm{C}$. The specimen surface has almost no damage, which indicates the specimen moved only by sliding on the metal tool surface, contrary to the measurements without a lubricant, where the specimen was moved by sliding and sticking (for $30 \% \mathrm{PF}$ resin-impregnated specimen at $140{ }^{\circ} \mathrm{C}$ in Fig. 7).

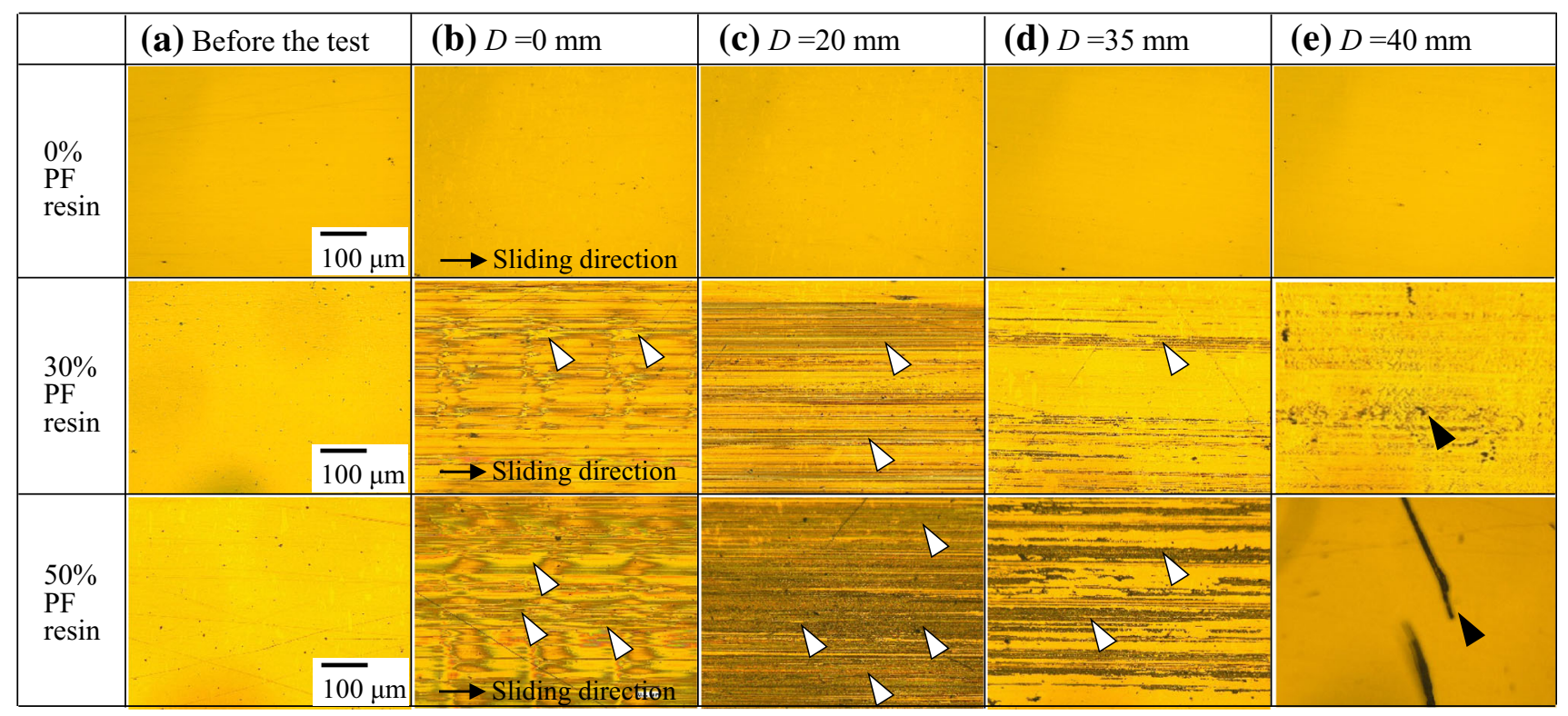

Fig. 9 Optical micrographs of metal tool surface before and after friction coefficient $(\mu)$ measurement at $140{ }^{\circ} \mathrm{C}$ for phenol formaldehyde (PF) resin concentrations of 0,30 and $50 \%$ at each stem displacement $(D)$. The triangles indicate gel-like adherents 


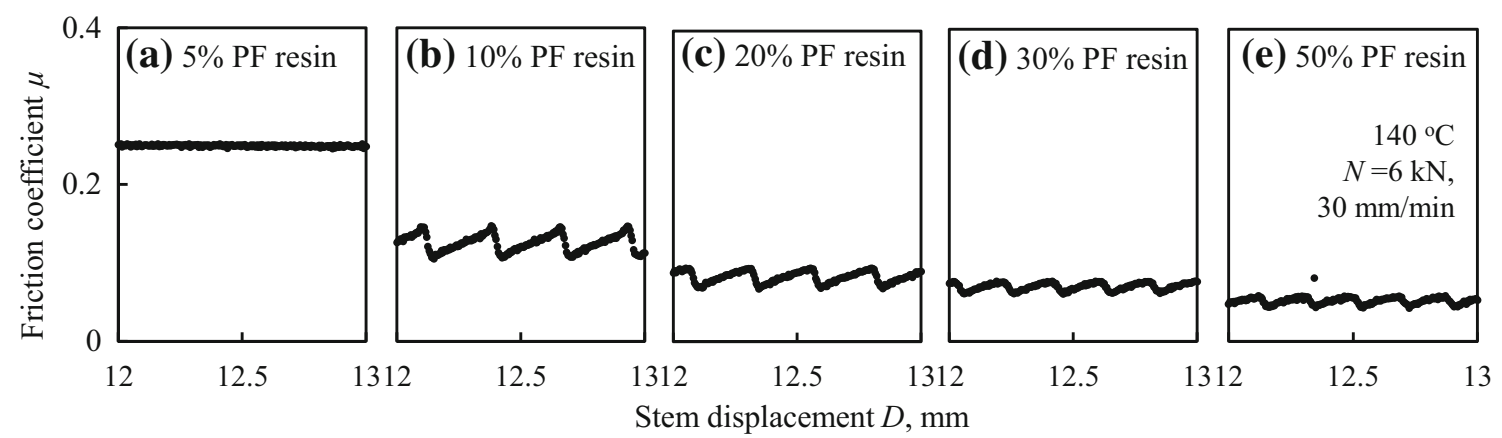

Fig. 10 Relationship between the stem displacement $(D)$ and friction coefficient $(\mu)$ for each phenol formaldehyde (PF) resin concentration at $140{ }^{\circ} \mathrm{C}$ (enlargement of Fig. 8 of $D=12-13 \mathrm{~mm}$ )

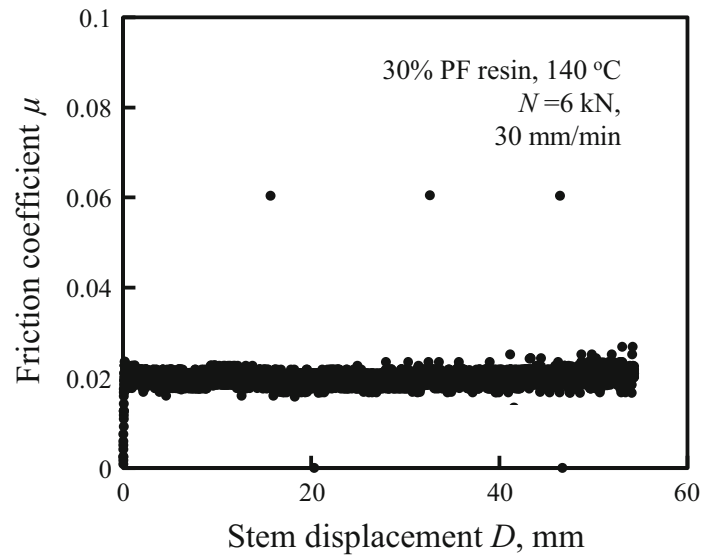

Fig. 11 Relationship between the stem displacement $(D)$ and friction coefficient $(\mu)$ when the metal tool surfaces were sprayed with a lubricant (phenol formaldehyde (PF) resin concentration of $30 \%$, $\left.140{ }^{\circ} \mathrm{C}\right)$
Fig. 12 Appearance of the $30 \%$ phenol formaldehyde (PF) resin-impregnated wood specimen after the friction coefficient $(\mu)$ measurement using a lubricant at $140{ }^{\circ} \mathrm{C}$

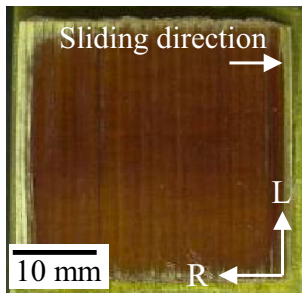

\section{Conclusions}

The effects of the metal tool surface temperature, the concentration of impregnated PF resin, and lubricants under exposure to high pressure on the friction characteristics between metal tools and PF resin-impregnated woods were investigated. $\mu$ was measured while the specimen was compressed in the tangential direction at high pressure (6.7 MPa). The following results were obtained.

1. The change in the behavior of $\mu$ for specimens impregnated with the lowest PF resin concentration
(5\%) was similar to that for non-impregnated wood. However, $\mu$ for a higher PF resin concentration of $30 \%$ differed significantly, depending on the temperature of the metal tool surface. Thus, the softening and hardening of the PF resin-impregnated specimens has a large effect on the friction characteristics. When the specimens slide under softening, PF resin seepage through the specimen surface contributes to a decrease of $\mu$ because PF resin acts as a lubricant when it is not cured. However, under hardening, curing in the PF resin-impregnated specimens near the contact surface increases the sliding resistance on the contact surface and generates sticking friction.

2. The amplitude and cycle of the stick-slip and the maximum value of $\mu$ during stick-slip which indicates the static friction coefficient decreased with an increase in the PF resin concentration at $140{ }^{\circ} \mathrm{C}$.

3. The use of a release agent for commodity plastics as a lubricant decreased $\mu$ to 0.02 and the specimen had almost no damage, in contrast to the specimens with no lubricant, which were damaged by sticking.

\section{References}

1. Sandberg D, Haller P, Navi P (2013) Thermo-hydro and thermohydro-mechanical wood processing: an opportunity for future environmentally friendly wood products. Wood Mater Sci Eng 8:64-88

2. Yamashita O, Yokochi H, Imanishi H, Miki T, Kanayama K (2006) Flow phenomenon of bulk wood (in Japanese). Trans Jpn Soc Mech Eng A 72:264-268

3. Miki T, Seki M, Sugimoto H, Shigematsu I, Kanayama K (2012) Mechanical properties of wood plastic composites prepared by wood flow forming using low molecular phenol resin. In: Proceedings of 11th pacific rim bio-based composites symposium, Bio-comp2012, Shizuoka, pp 154-161

4. Miki T, Seki M, Sugimoto H, Shigematsu I, Kanayama K (2013) Preparation of three dimensional products using flow deformability of wood treated by small molecular resins. Adv Mater Res 856:79-86 
5. Stamm AJ, Seborg RM (1936) Minimizing wood shrinkage and swelling: treating with synthetic resin-forming materials. Ind and Eng Chem 28:1164-1169

6. Shams MI, Yano H, Endou K (2004) Compressive deformation of wood impregnated with low molecular weight phenol formaldehyde (PF) resin I: effects of pressing pressure and pressure holding. J Wood Sci 50:337-342

7. Stamm AJ, Seborg RM (1955) Forest Products Laboratory resintreated, laminated, compressed wood (compreg). Forest Prod Lab Report 1381 Rev

8. Seki M, Nakatani T, Sugimoto H, Miki T, Kanayama K, Furuta Y (2012) Effect of anisotropy of wood on friction characteristics under high pressure conditions (in Japanese). J Soc Mater Sci 61:335-340

9. Seki M, Sugimoto H, Miki T, Kanayama K, Furuta Y (2013) Wood friction characteristics during exposure to high pressure: influence of wood/metal tool surface finishing conditions. J Wood Sci 59:10-16

10. Seki M, Sugimoto H, Miki T, Kanayama K, Furuta Y (2012) Wood friction characteristics during exposure to high pressure: influence of moisture content of wood (in Japanese). Mokuzai Gakkaishi 58:302-308

11. Murase Y, Ota M (1973) Studies on the frictional characteristics of wood I: the explanation based on the adhesion component and deformation component (in Japanese). Mokuzai Gakkaishi 19:421-425

12. ISO 4287-1997 (2009) Geometrical product specification (GPS). Surface texture: profile method. Terms, definitions and surface texture parameters. International Organization for Standardization, Geneva

13. Furuno T, Imamura Y, Kajita H (2004) The modification of wood by treatment with low molecular weight phenol-formaldehyde resin: a properties enhancement with neutralized phenolic-resin and resin penetration into wood cell walls. Wood Sci Technol 37:349-361

14. Shams MI, Yano H (2004) Compressive deformation of wood impregnated with low molecular weight phenol formaldehyde (PF) resin II: effects of processing parameters. J Wood Sci 50:343-350

15. Dieter GE (1986) Fundamentals of metal working. Mechanical metallurgy. McGraw-Hill Int Ed, New York, p 542

16. Bowden FP, Tabor D (2001) Mechanism of metallic friction. The friction and lubrication of solids. Clarendon press, Oxford, pp 98-111

17. McKenzie WM, Karpovich H (1968) The frictional behavior of wood. Wood Sci Technol 2:139-152 